\title{
Chlamydial infection
}

\section{Improved methods of collection of material for culture from the urogenital tract and rectum}

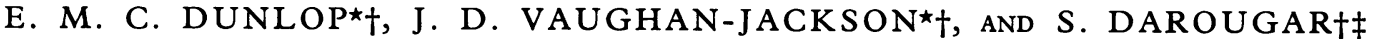 \\ From the Whitechapel Clinic, The London Hospital ${ }^{\star}$, and the Department of Clinical Ophthalmology $\dagger$ and the \\ Virus Laboratory $\ddagger$ Institute of Ophthalmology, London
}

Material for culture for Chlamydia in cell culture has been collected from the urethra in the cases of men and from the cervix, urethra, and ano-rectal canal in the cases of women. The results of different methods of collection have been compared. The methods have been reported by Dunlop and his colleagues (1964, 1965, 1969, 1971); the cell-culture techniques used were the simplified methods of Darougar, Kinnison, and Jones (1971a, b).

\section{Methods}

(a) Tests of the urethra in men

With the patient lying on his back on a couch, material from the urethral meatus and distal urethra was collected

Received for publication September 8, 1972

Presented at the Jubilee Meeting of the M.S.S.V.D. held in Glasgow June 8 to 11,1972 with a cotton-wool swab made by Stayne Laboratories Ltd. (Figure a). The swab was then moistened in the specimen container of sucrose-phosphate solution with antibiotics (2 SP) with serum; any excess of fluid was removed by rotating the swab while gently pressing it against the upper part of the inside of the container. The swab was then re-inserted into the urethral meatus and rotated before being returned to the container of $2 \mathrm{SP}$ with serum and broken off.

A wet smear and a dry smear of the urethral secretion were made by using a bacteriological loop passed wello ? into the urethra.

Stuart's swabs were then used to collect material from the urethral meatus for culture for bacteria, for $T$. vaginalis, and for mycoplasmas. The patient then got up, passed urine, returned to the couch, and lay down as before.

1 to $2 \mathrm{ml}$. of plain lignocaine 0.5 per cent. was instilled into the urethra with a disposable syringe, the urethral

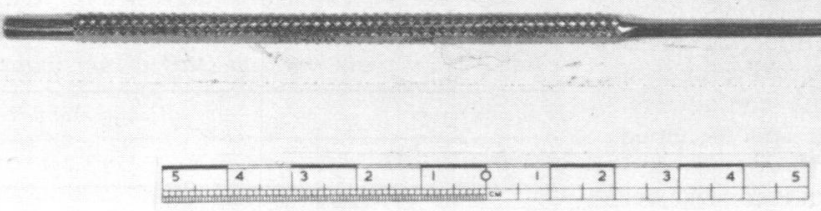

FIGURE Instruments used for testing the urethra in men

(a) Meatal swab (made by Stayne Laboratories Ltd)

(b) Endourethral swab (made by Medical Wire and Equipment Co. Ltd)

(c) Endourethral curette (made by Down Brothers and Mayer and Phelps Ltd)

The cotton-wool on the endourethral swab is tightly wound; it is $3 \mathrm{~mm}$. in diameter, 12 to $15 \mathrm{~mm}$. in length 
meatus was compressed and the lignocaine retained for from 1 to 2 minutes before being allowed to escape from the urethra.

An endourethral swab (Figure $b$ ) made by the Medical Wire and Equipment Co. Ltd was passed dry as far into the anterior urethra as possible; it was then withdrawn and agitated in the container of 2 SP and serum, after which excess fluid was removed as before. The swab was then re-inserted into the urethra. This swab, particularly after moistening, was readily passed to the urethral bulb. It was finally removed and placed in the container of 2 SP with serum, and the wire shaft was cut with clippers, the cutting ends of which had been sterilized by dipping in spirit and then passing through a flame.

Endourethral scrapings were then taken using a curette (Figure $c$ ) made by Down Brothers and Mayer and Phelps Ltd (Dunlop and others, 1964, 1965). This curette was passed to the urethral bulb and scrapings were taken from the whole length of the anterior urethra at the 12, 3, 6, and 9 o'clock positions; the curette was washed in the container of 2 SP and serum after each scraping and surplus fluid was removed by tapping the curette against the inside of the container.

(b) Tests of the cervix, urethra, and rectum in women (1) CERVIX

Under direct vision, using an operating microscope, the marginal area of the cervix was rubbed, before other tests were taken, with a cotton-wool swab (Figure a) made by Stayne Laboratories Ltd, concentrating upon any inflamed areas. A smear of the endocervical secretion, material on a Stuart's swab for culture, scrapings of the marginal area (particularly of inflamed areas) using a cervical scraper made by Down Brothers and Mayer and Phelps Ltd (Dunlop and others, 1964), and a cervical biopsy specimen were then taken.

\section{(2) URETHRA}

Before material was taken for other tests from the urethra a cotton-wool swab (Stayne Laboratories Ltd) was inserted into the urethral meatus. It was then agitated in 2 SP with serum and surplus liquid was squeezed out by rotating it against the inside of the container; the swab was then re-inserted into the urethral meatus, rotated, and withdrawn. It was finally broken off into the container.

\section{(3) RECTUM}

Material for culture for Chlamydia was collected under direct vision, using an operating microscope, first with a cotton-wool swab (Stayne Laboratories Ltd) which was rubbed over the surface of the anorectal mucous membrane; scrapings were then taken by means of a scraper of flattened aluminium wire as used for the conjunctiva. This scraper was less abrasive than the spoon-shaped cervical scraper or the urethral curette and was also less efficient than either for holding material on it for transfer to the container.

Before these swabs were used for the collection of material for testing for Chlamydia, studies in the laboratory showed that they had no adverse effect upon monolayers of irradiated McCoy cells as used for culture.
TABLE I Isolation of Chlamydia frompositive urethral material collected by different methods from 52 men

\begin{tabular}{|c|c|c|c|}
\hline \multirow{2}{*}{ Method of collection } & \multirow{2}{*}{$\begin{array}{l}\text { No. of patients } \\
\text { tested }\end{array}$} & \multicolumn{2}{|c|}{ Isolate obtained } \\
\hline & & No. & Per cent. \\
\hline (a) Meatal swab & 48 & 32 & 67 \\
\hline (b) Endourethral swab & 33 & 28 & 85 \\
\hline (c) Urethral curette & 51 & 47 & 92 \\
\hline
\end{tabular}

Methods $(b)$ and $(c)$ are significantly more effective than Method $(a)$ $\left(\chi^{2}=10.8764 ; P=<0.01\right)$

There is no significant difference between methods $(b)$ and $(c)$ $\left(x^{2}=2.0131 ; P=>0.1\right)$

\section{Results}

\section{(a) Tests of the urethra in men}

The results of culture in cell culture for Chlamydia of positive urethral material collected by these different methods from men are shown in Table I. Urethral material from each patient was collected by at least two and usually by all three methods. The Table shows the results of tests of urethral material which was shown to contain Chlamydia by one or more methods of obtaining material. Of 48 meatal swabs, 32 (67 per cent.) gave positive results; of 33 endourethral swabs, 28 ( 85 per cent.) gave positive results; of 51 urethral scrapings collected with a curette, 47 (92 per cent.) gave positive results. Meatal swabs were significantly less effective in obtaining positive results than endourethral swabs or the endourethral curette. The last two methods gave similar results.

An additional series of 135 men who had presented because of non-specific urethritis (NSU) were tested by means of meatal swabbing carried out by male nurses (Table II). Chlamydia was isolated from only 14 per cent. which is in keeping with the lower sensitivity of this method found for tests carried out in parallel by a physician on positive material (Table I) and in NSU. The incidence of positivity in that condition was 26 per cent. for material collected with a meatal swab, compared with 39 per cent. for that collected by a curette, and 37 per cent. for that collected by an endourethral swab (Dunlop, VaughanJackson, Darougar, and Jones, 1972).

TABLE II Results of cell culture for Chlamydia of meatal material collected from men presenting because of NSU by male nursing staff using swabs

\begin{tabular}{ll}
\hline Patients tested & Isolate obtained \\
\hline 135 & $19(14 \cdot 1$ per cent.) \\
\hline
\end{tabular}

(b) Tests of the cervix, urethra, and rectum in women (1) CERVIX

The results of testing cervical material shown to contain Chlamydia by culture in cell culture of 
material obtained from the cervix by swab, or scraper, or both is shown in Table III.

TABLE II I Isolation of Chlamydia from positive cervical material collected using swab and scraper from different groups of patients

\begin{tabular}{|c|c|c|c|}
\hline Group & $\begin{array}{l}\text { No. of sets } \\
\text { of tests }\end{array}$ & $\begin{array}{l}\text { Swab } \\
\text { positive }\end{array}$ & $\begin{array}{l}\text { Scrape } \\
\text { positive }\end{array}$ \\
\hline $\begin{array}{l}\text { Female contacts of men } \\
\text { suffering from NSU }\end{array}$ & 16 & 13 & 15 \\
\hline $\begin{array}{l}\text { Women suffering from } \\
\text { ocular infection due to } \\
\text { TRIC agent }\end{array}$ & 31 & 22 & 30 \\
\hline $\begin{array}{l}\text { Female contacts of men } \\
\text { suffering from ocular infec- } \\
\text { tion due to TRIC agent }\end{array}$ & 6 & 5 & 5 \\
\hline $\begin{array}{l}\text { Mothers of babies suffering } \\
\text { from ophthalmia neonatorum } \\
\text { due to TRIC agent }\end{array}$ & 15 & 11 & 11 \\
\hline Total & 68 & $\begin{array}{l}51(75 \text { per } \\
\text { cent. })^{\star}\end{array}$ & $\begin{array}{l}61(90 \text { per } \\
\text { cent. })^{\star}\end{array}$ \\
\hline
\end{tabular}

In all, 68 sets of tests were performed on cervical material from which Chlamydia was obtained: a scraper gave positive results in 61 cases $(90$ per cent.), a swab in 51 (75 per cent.); thus the scraper was significantly more effective than the swab.

\section{(2) URETHRA}

In one case in which material obtained with a meatal swab gave a negative result, that obtained with an endourethral curette gave a positive result (Dunlop, Darougar, Hare, Treharne, and Dwyer, 1972). In this case, and all others from which Chlamydia was obtained from the urethra, an isolate was obtained from the cervix. Urethral material from women was obtained by different methods in insufficient numbers for any valid comparison of methods to be made.

\section{(3) RECTUM}

In nine cases positive material was obtained by swab, simple scraper, or both. In seven, material obtained with a swab gave positive results; in seven, material obtained with a scraper gave positive results (Table IV).

TABLE IV Isolation of Chlamydia from positive anorectal material collected using swab and simple scraper

\begin{tabular}{lll}
\hline Sets of tests & Swab positive & $\frac{\text { Scrape positive }}{7}$ \\
\hline 9 & 7 & 7 \\
\hline
\end{tabular}

Because this simple scraper is less effective than a swab for obtaining material for cell culture from the conjunctiva (Darougar and Jones, 1970) a swab is now used for collecting material from the rectum for culture for Chlamydia.

\section{Discussion}

Results obtained by collecting material from the urethra of the male with an endourethral swab are statistically similar to those obtained with a curette. As a result the endourethral swabs are being used in the study of a 'control' group and for repeated tests to assess the results of treatment of chlamydial infection of the urethra in men.

Not surprisingly, the cervical scraper afforded a rather more efficient method for collecting material from the cervix than did the swab, but the swab is sufficiently effective to be used when scraping is impracticable.

\section{Summary}

In tests of urethral material containing Chlamydia from 52 men, 48 meatal swabs gave positive results in 32 cases ( 67 per cent.). This compared with positive results from 47 (92 per cent.) of 51 scrapings with a curette and 28 (85 per cent.) of 33 endourethral swabs.

The meatal swab clearly provided a less effective method for obtaining positive material than the endourethral swab or the curette. Results with the endourethral swab were sufficiently good to allow it to be used for the study of 'control' groups and for the assessment of the results of treatment of chlamydial infection of the urethra in men.

In 68 tests of cervical material containing Chlamydia, swabs gave positive results in 51 (75 per cent.), scrapers in 61 (90 per cent.). The cervical scraper was the more effective method for obtaining positive material but the swab was sufficiently effective to be used in cases in which scraping is impracticable. In the small numbers of cases in which anorectal material containing Chlamydia was obtained by means of a swab and by a simple scraper, as used for the conjunctiva, the incidence of positivity for the two methods was the same.

We are grateful to our colleagues who referred patients to us for investigation; to Dr. A. E. Wilkinson, Director of the V.D. Reference Laboratory, The London Hospital, for carrying out serological tests for syphilis, and cultures for bacteria, Trichomonas vaginalis, and Candida; to Mrs. Bryony Phillips, B.Sc., of the Computer Section, Institute of Ophthalmology, for statistical advice; and to the Department of Audio-visual Communications of 
The Institute of Ophthalmology for the illustration. We thank the London Hospital for financial support, and the Research and Development Division of the Department of Health and Social Security for a grant in support of the laboratory work at the Institute of Ophthalmology.

\section{References}

Darougar, S., and Jones, B. R. (1970) Brit. F. Ophthal., 55, 585

- Kinnison, J. R., and Jones, B. R. (1971a) In 'Trachoma and Related Disorders', ed. Roger $L$. Nichols, p.63. Excerpta Medica, Amsterdam and New York

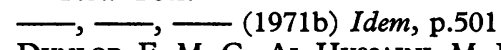

Dunlop, E. M. C., Al-Hussaini, M. K., Garland, J. A., Treharne, J. D., Harper, I. A., and Jones, B. R. (1965) Lancet, 1, 1125, 1286

-, Darougar, S., Hare, M. J., Treharne, J. D., and DWYER, R. St. C. (1972) Brit. med. F., 2, 386

- , HARE, M. J., Darougar, S., and Jones, B. R. (1971) In 'Trachoma and Related Disorders', ed. R. L. Nichols, p.494. Excerpta Medica, Amsterdam and New York

\footnotetext{
Dis., 120, 463

- Jones, B. R., and Al-Hussaini, M. K. (1964) Brit. F. vener. Dis., 40, 33

- Vaughan-Jackson, J. D., Darougar, S., and JONES, B. R. (1972) Ibid., 48, 425
}

\section{Infection chlamydiale}

Méthodes améliorées pour la récolte du matériel de culture à partir des voies uro-génitales et du rectum

\section{SOMMAIRE}

Dans les épreuves pratiquées sur le matériel urétral contenant des Chlamydia chez 52 hommes, 48 écouvillons provenant du méat donnèrent des résultats positifs dans 32 cas (67 pour cent). En comparaison, les résultats furent positifs pour 47 (92 pour cent) de 51 grattages avec une curette et pour 28 ( 85 pour cent) des 33 écouvillonnages endo-urétraux.

Il est clair que l'écouvillonnage du méat est une méthode moins efficace pour obtenir un matériel positif que l'écouvillonnage endo-urétral ou la curette. Les résultats, avec l'écouvillonnage endo-urétral, ont été suffisamment bons pour qu'il puisse être utilisé dans l'étude de groupes témoins ou pour l'estimation des résultats du traitement de l'infection chlamydiale de l'urètre chez les hommes.

Dans 68 tests sur du matériel cervical contenant des Chlamydia, les écouviilons donnèrent des résultats positifs pour 51 (75 pour cent), les grattages pour 61 ( 90 pour cent). Le grattage cervical fut la méthode la plus efficace pour obtenir un matériel positif, mais l'écouvillon est suffisant pour les cas où le grattage est impraticable. Dans le petit nombre de cas dans lesquels le matériel ano-rectal contenant des Chlamydia fut obtenu au moyen d'un écouvillon ou par un simple grattage, comme ceci se fait pour la conjonctivite, l'incidence de positivité fut la même pour les deux méthodes. 